\title{
Belgeo
}

Revue belge de géographie

4 | 2017

La Belgique : quelques nouveaux regards sur un pays

en forte mutation - Belgium: some new looks at a

higly evolving country

\section{The impact of the 2016 terrorist attacks in Brussels on tourism}

Dominique Vanneste, Petronela Tudorache, Flavia Teodoroiu and Thérèse Steenberghen

\section{OpenEdition}

\section{Journals}

\section{Electronic version}

URL: http://journals.openedition.org/belgeo/20688

DOI: 10.4000/belgeo.20688

ISSN: 2294-9135

Publisher:

National Committee of Geography of Belgium, Société Royale Belge de Géographie

\section{Electronic reference}

Dominique Vanneste, Petronela Tudorache, Flavia Teodoroiu and Thérèse Steenberghen, « The impact of the 2016 terrorist attacks in Brussels on tourism », Belgeo [Online], 4 | 2017, Online since 01 March 2018, connection on 10 December 2020. URL : http://journals.openedition.org/belgeo/20688 ; DOI : https://doi.org/10.4000/belgeo.20688

This text was automatically generated on 10 December 2020.

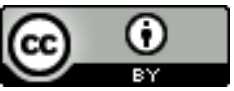

Belgeo est mis à disposition selon les termes de la licence Creative Commons Attribution 4.0 International. 


\title{
The impact of the 2016 terrorist attacks in Brussels on tourism
}

\author{
Dominique Vanneste, Petronela Tudorache, Flavia Teodoroiu and \\ Thérèse Steenberghen
}

\section{Introduction}

1 Scientists as well as the general public remember the terrorist attacks that took place in Brussels in March 2016, with 32 people killed at two different sites and ca. 300 injured $^{1}$. This was not a standalone event since previous to these, Paris was startled with horror on November 2015 and Nice was badly hit on the French National Holiday in 2016 while southern Germany experienced one (or several) attack(s) at four different places between July 18 and July 24, 2016. For sure, this reshapes people's perception of places - in tourism terms, destinations - and may affect tourists' behavior. Terrorist attacks have become a fact of life and therefore it's important to analyze and monitor in what ways these events affect the tourism industry and tourists' behavior as a prerequisite for future crisismanagement measures. In other words, for future tourism policy, tourism marketing and management and tourism product and destination development, it is important to gain insights in the perception of visitors according to the do's and don'ts in a city or country that experience(d) one (or several) terrorist attacks, as well as what to do to rehabilitate the damaged image of an affected destination.

2 In this paper, we explore the effects of the terrorism events mainly from the demand side. In fact, the influence of such attacks on the supply side becomes very clear soon since the number of (international) arrivals, overnight stays and hotels' occupancy rates tend to respond very quickly, affected by tourists staying away. It is much more difficult to detect the feelings and changes of attitude among tourists.

3 In an attempt to measure how hard a destination is hit by such a terrorist attack we will tackle two questions. The first question is related to the (dynamics of) numbers, based on available statistical data (comparison between 2015 and 2016 depending on availability). The second question which is harder to elaborate, is related to the feelings and attitudes 
of those tourists who do not cancel their plans and who do not want their lives and choices to be affected by such events but nevertheless might change their behavior. Indeed, monitoring relies on a constant flow of data which is available on the supply side (e.g. hotel barometer) but the visitors' attitudes and perceptions are much harder to measure. Therefore, this paper focusses in particular on the latter.

Our research is mainly centered on Brussels which cashed the attacks but we used Antwerp and Bruges as a benchmark. Brussels, capital of Europe and therefore a clear target, is Belgian's capital and its largest city with 1,188 million inhabitants ${ }^{2}$ was hit twice, once in the heart of its center (metro station in the European quarter) and once at its airport on March 22, 2016. Antwerp is the second largest city in Belgium (almost 514 thousand inhabitants) and one of the major ports in Europe and in the world. Therefore Antwerp receives a mix of international visitors for many purposes and is very popular for city trips and shopping among visitors from the Netherlands. Bruges, although a smaller city (118 thousand inhabitants) is internationally well known since it carries the Unesco World Heritage label since 2000 and therefore attracts many tourists from all over Europe and beyond (nearly 8 million in 2015 ${ }^{3}$ ). Therefore, it seemed interesting to question visitors in all of these destinations about their feelings of safety in Belgium as a country and in the city, as well as strategies coping with feelings of unsafety, if any.

The research for this article was conducted in two steps. The first one, based on desk research, intends to frame the consequences of a terrorist attack by confronting the reader with a number of statistics that show the effect on a number of indicators for the destination, in this case Belgium and Brussels. In a second step, focusing on a deeper understanding and interpretation of the figures and impact on visitors' behavior, we present the results of a survey, held in Brussels and additionally in Antwerp and Bruges as a kind of benchmark. Before doing so, we elaborate a few general topics on terrorism and violence and their impact on tourism, based on academic literature as well as a section on methodology. Finally we will share our results and reflections in terms of policy and management.

\section{Frame: the terrorism-tourism dialectic}

6 The aim of conducting this literature review is to providing a common understanding of the topic based on previous research on similar circumstances. Defining 'terrorism' is not easy. We can refer to Enders and Sandler (2002), Ganor (2010) or Crenshaw and LaFee (2017) who address the START-Global Terrorism Database definition ${ }^{4}$. Looking from a terrorist's perspective, violence is a deliberately pursued characteristic, meant to affect a target audience beyond the immediate victims and to influence the audience as part of an attempt to serve the political objectives of an organization. Some definitions specify that the targets of terrorist violence are civilians while the terrorist actions are used to improve the power position of the [identifiable] organization from a political perspective (Lutz et al., 2002; Lutz \& Lutz, 2009; Korstanje, 2013; Ranga \& Pradhan, 2014). For sure, 'civilians' include residents as well as visitors.

7 From a tourism perspective, the primary conditions for a normal tourism development of a destination, region, or country refer to peace and the safety of the tourists. Without them, destinations are not competitive, even if they present the most attractive and best quality natural and built attractions in their marketing campaigns (Cavlek, 2002; Gupta, 2011). Tourists will therefore hesitate to travel to/in countries where the political-social 
situation is unstable or violent. The basic rationale of the literature on international tourists' requirements is the balance between the attractiveness of a country and the costs, or risks, of visiting the destination (Goldman \& Neubauer-Shani, 2017).

8 According to Edkins et al. (2004), there is a big correlation between international terrorism and tourism. Terrorists are motivated to attack the tourists or the tourist industry. For instance they want to damage the economy of a country or they want to gain international attention and publicity.

9 As early as the last decades of last century, several theoretical and empirical studies offered valuable and advanced understanding of the unique relationship between terrorism and tourism (Richter 1983; Richter and Waugh, 1986; Aziz, 1995; Wahab 1996; Sönmez, 1998 and 1999; Feichtinger et al., 2001). Richter (1983) suggests that travelers might be targeted for violent attacks because they are perceived as ambassadors of their countries and also because they are "soft" targets. When tourists are victimized, the situation is immediately amplified by the media and the political conflict between terrorists and the establishment is transferred to a much wider scale of international attention. The tourist's country becomes involved in the situation and further involvement of other countries intensifies the pressure on the government of the targeted destination. This is confirmed by Sönmez $(1998,1999)$ and later studies (a.o. Gupta, 2011; Fuchs et al., 2012; Ranga and Pradhan, 2014; Albu, 2016; Goldman and Neubauer-Shani, 2017). Richter and Waugh (1986) put the relationship very clear in the title of their paper "Terrorism and tourism as logical companions". The effects of terrorist activities go far beyond the actors and services that are directly linked with tourism such as hotels and catering, airlines, guided tours etc.; they effect also those who supply goods and services to the firms operating in the tourism industry (Kalia, 2009). Terrorism impacts significantly the tourism industry, which further affects the general economy and terrorists are very much aware of this. Additionally, tourists are easy targets (Kamrava, 2011).

10 It is common knowledge that, before making a decision to travel to a destination, tourists develop an amount of expectations based on their past experiences, adverts, common beliefs and influences from friends and relatives (Um and Crompton, 1990; Seddighi and Theocharous, 2002; Sönmez and Graefe, 1998) while the role of the media cannot be overestimated (Butler, 1990; Burns et al., 2010). Tourists can modify their destination choices, their travel behavior for protection, safety and security. They decide to continue or change their destination plans by getting information on terrorism, crime, and incidents, political turmoil; this information can continue to influence destination choices, even when situations change and the information becomes outdated (McGuckin and Demick, 2000). Travelers who decide to travel despite of risk, are advised by different sources (news, government advisories and travel magazines) to avoid a display of wealth and to keep low profile (Chandler, 1991). On the other hand, Larsen et al. (2009) developed a Tourist Worry Scale to measure worries regarding typical negative outcomes of tourist visits and found that tourists tend not to worry much about terrorism. The same goes for the results by Wolff and Larsen (2014) who examined the effect of the Oslo/Utoya massacres (2011) on short- and long-term risk perception and worries among tourists; they found it to be relatively small. On the other hand, Wolff and Larsen (2014) point out that the areas where terrorism occurred are less frequented by tourists, with the result that local citizens, tourists, and the tourism industry are all directly affected. This produces a short- and long-term effect on tourism demand, from cancellation of bookings 
and reduction in new bookings to reductions in global travel. It is interesting to mention that Fuchs et al. (2012) found that tourists who neglected governmental advisories and travelled to destinations threatened by terrorism reported low to moderate perceived risk about terrorism, and used different rationalizations to reduce their worries.

Internationally, news that relates to terrorism and political turmoil spreads at a fast rate because governments care for the wellbeing of people and would not want them to be exposed to the dangers of terrorism but to some extent, media highlight the events to some extreme level as if they 'kick' on the big declarations, the panic communication and the instant reporting from symbolic places. Further, many countries spend a lot of money to prevent terrorism, increase the development of academic research institutions or implement new education programs for the study of security of countries and counterterrorism (Keohane, 2005). News about terrorism is given special attention internationally and therefore this can have a big and instant impact on the tourism field.

In cases of attacks on tourists, the ministry of tourism is not the only authority which needs to undertake measures to overcome the problem. Its policies and actions have to be supported by necessary measures taken by the ministry of foreign affairs and the ministries of transport, culture, economic affairs etc. The importance of government actions is reflected by the fact that its agencies try to co-ordinate activities with the ministry of tourism, national tourist organizations, foreign tour operators, local travel organizers, airline companies (national and international), hoteliers, and other related organizations, try to give the media accurate information about the crisis because credibility is critical to this process, try to inform the media about the steps taken in the country to solve the problem, try to make use of media interest in the country to broadcast positive facts, try to invite journalists, tour operators and travel agents to the destination to show them the real situation and try to promote the destination on foreign markets, so that it stays present in the minds of potential tourists or regains a positive connotation (McGuckin and Demick 2000; Cavlek, 2002).

\section{Methodology}

13 As mentioned in the introduction, this research was conducted in two steps: a desk research on a number of indicators and a survey on the interpretation and attitude towards the events.

14 First, we explore a number of data on indicators that have the potential of reflecting the impact of any hazard or acute crisis on tourism. The number of (international) arrivals, the number of overnight stays (number of nights spend at a destination), and the occupancy rate of accommodations are the most important (and most available) at a destination level, while the booking behavior, the number and orientation of departures is very revealing on the side of the markets of origin. In this case, we focus on the destination perspective (inbound) and especially on statistics that allow us to follow the evolution month by month (time series approach). These data are not perfect. The number of overnight stays is only reflecting the reported nights by official accommodations. Nights spend with family and friends or in airb\&b are not taken into account. The same goes for the number of arrivals. Arrivals that can be registered since they are linked with a ticketing system (e.g. by plane, international trains etc.) can be counted but visitors who travel by their own, individual means escape our attention. In our case, the number of air passengers is particularly interesting since it serves two 
purposes: it reveals the recovery of the Brussels Airport as a gateway which was directly hit and heavily damaged and it indicates how quickly visitors regain trust in the modus of travel and in the destination. Nevertheless, these figures are not the core of this article; the figures rather contribute to the problem statement, setting the scene for the main and original contribution of this article on the attitude and behavior of visitors.

The second and most important phase consisted of a survey. Although this second phase is about attitudes, perceptions and reflections and therefore a qualitative research method could be considered, we opted for a quantitative method. This is based on earlier experience that interviews with tourists (or visitors in general) in the field are very difficult because most tourists feel time constraints and do not want to spend (loose) time by talking to a stranger about an unpleasant subject. A second element has to do with language: the survey could be easily translated and conducted in four languages (Dutch, French, English and Spanish) while an interview in all of these languages was not feasible. Finally, we aimed at having some external validity which means that we can generalize our results. Therefore, the number of respondents for Brussels (more than 314) is somewhat below the recommended number (385) to obtain a $95 \%$ statistical reliability (with $5 \%$ error rate) but far above a $90 \%$ statistical reliability. The lower number was due to a considerable number of non-response (see below).

To go beyond the closed questions and to gain some qualitative information, a number of open questions were asked, as well as a number of statements that could be graded from strongly disagree to strongly agree. The questionnaire consisted of three categories of questions, such as general questions (10) on how the tourists chose the tourist destination, length of their stay, the activities they want to do or did in the city, the way of travelling; questions about terrorist attacks (13) and their influence on the decision of the respondents in choosing Brussels, Bruges or Antwerp as a tourist destination and the demographic questions (4) such as age, gender, nationality and company or party.

The survey was conducted from the beginning of August till the beginning of September 2016, starting with a test pilot in Brussels in order to see which questions from the questionnaire were really relevant or badly understood. We used systematic random sampling, taking every 10th person that came by. We interviewed domestic and international visitors, which means that people living, working or studying in Brussels were not taken into account. We focused on people over (estimated) 18 years old. After eight days of fieldwork in Brussels (which was the time budget), the team moved to the benchmarking cities where fieldwork was done during four days in Antwerp and four days in Bruges.

In all the three cities, the team tried to spread across the historic city, interviewing people near main tourism sites but also at less well-known or promoted spots (24 in Brussels; 19 in Antwerp; 18 in Bruges). The questionnaires were administered in 4 languages: Dutch, French, English and Spanish. The survey data were integrated in a database that was analyzed in a quantitative way using uni-variate, bi-variate and multivariate statistics.

19 The total number of the respondents was: 314 in Brussels, 150 in Bruges and 139 in Antwerp. The team was confronted with a considerable non-response (186 in Brussels, 116 in Antwerp and 93 in Bruges) which consisted mainly of older people (55\% in Brussels; 59\% in Antwerp and 63\% in Bruges) and a considerable number of Asian tourists. The latter might be related to the fact that people who refused to participate in the survey belonged to groups with very little time to visit the city. 
Not only the number but also the characteristics of the sample can influence the results. Therefore, before describing and discussing the results, the profile of the sample is presented using a number of graphs. First we present a number of demographics (age, origin and company) and second, we give some travel characteristics (basis for decision, kind/purpose, activities) (Figure 1).

Figure 1. Profile of the respondents in the Brussels, the Antwerp and the Bruges sample.

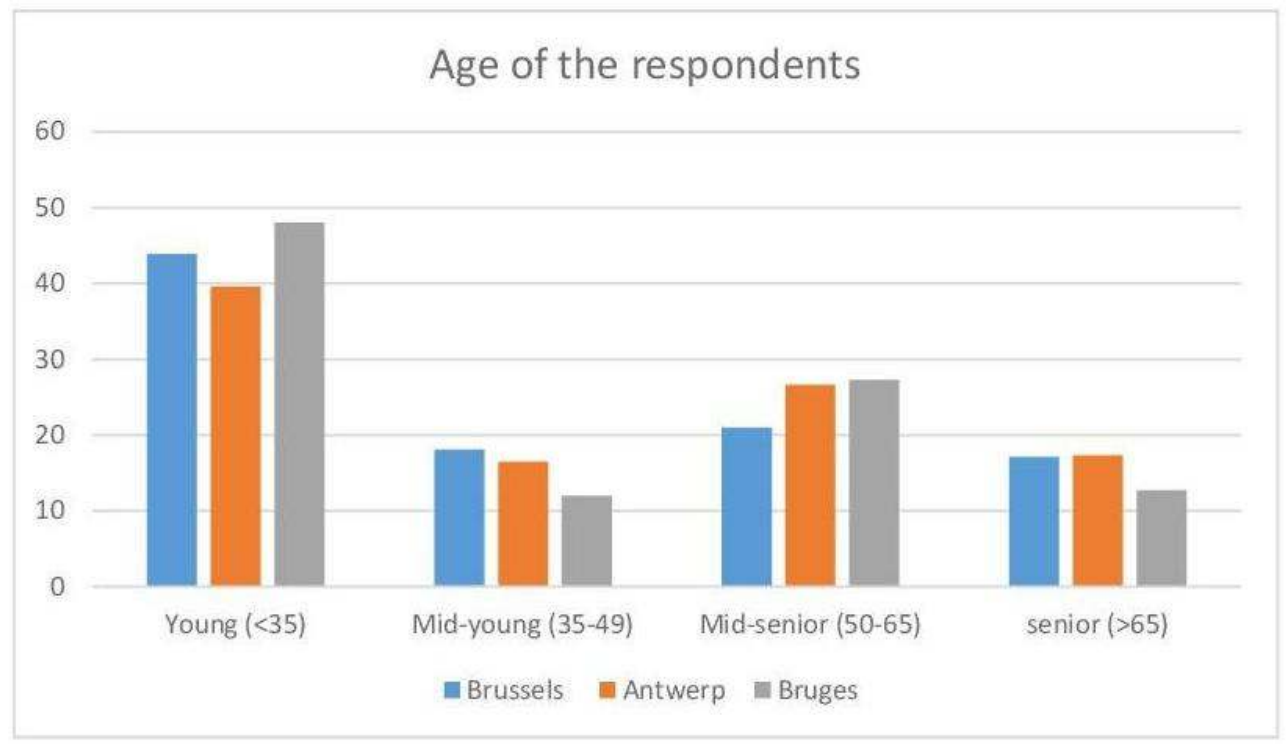

Source: own survey, 2016

\section{Origin of repondents}

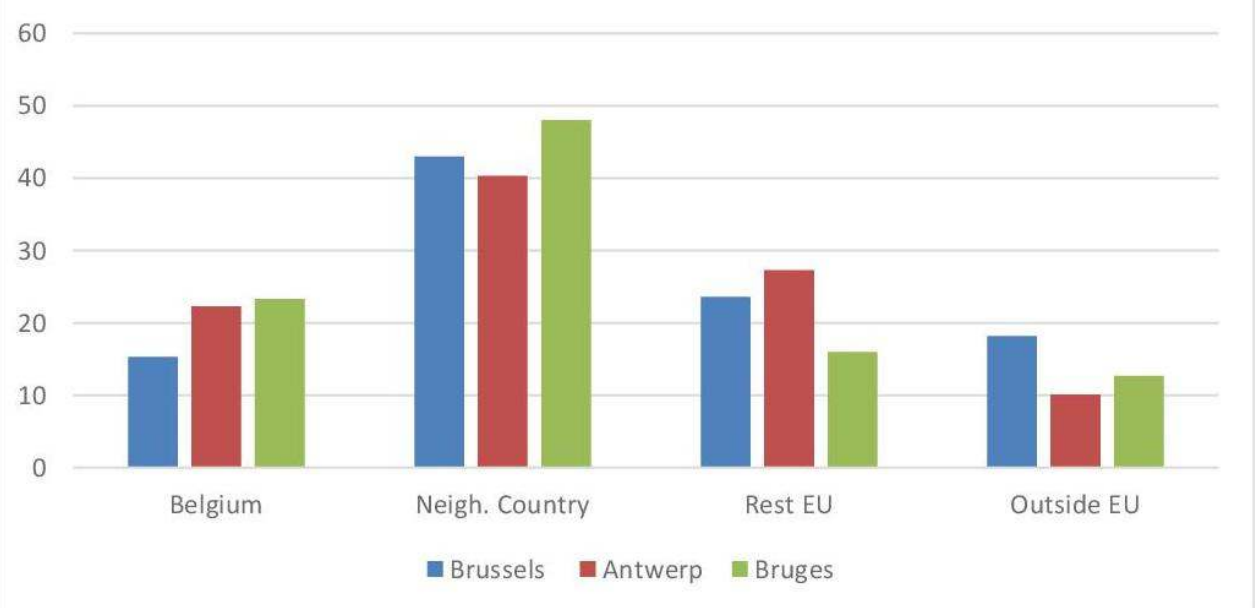



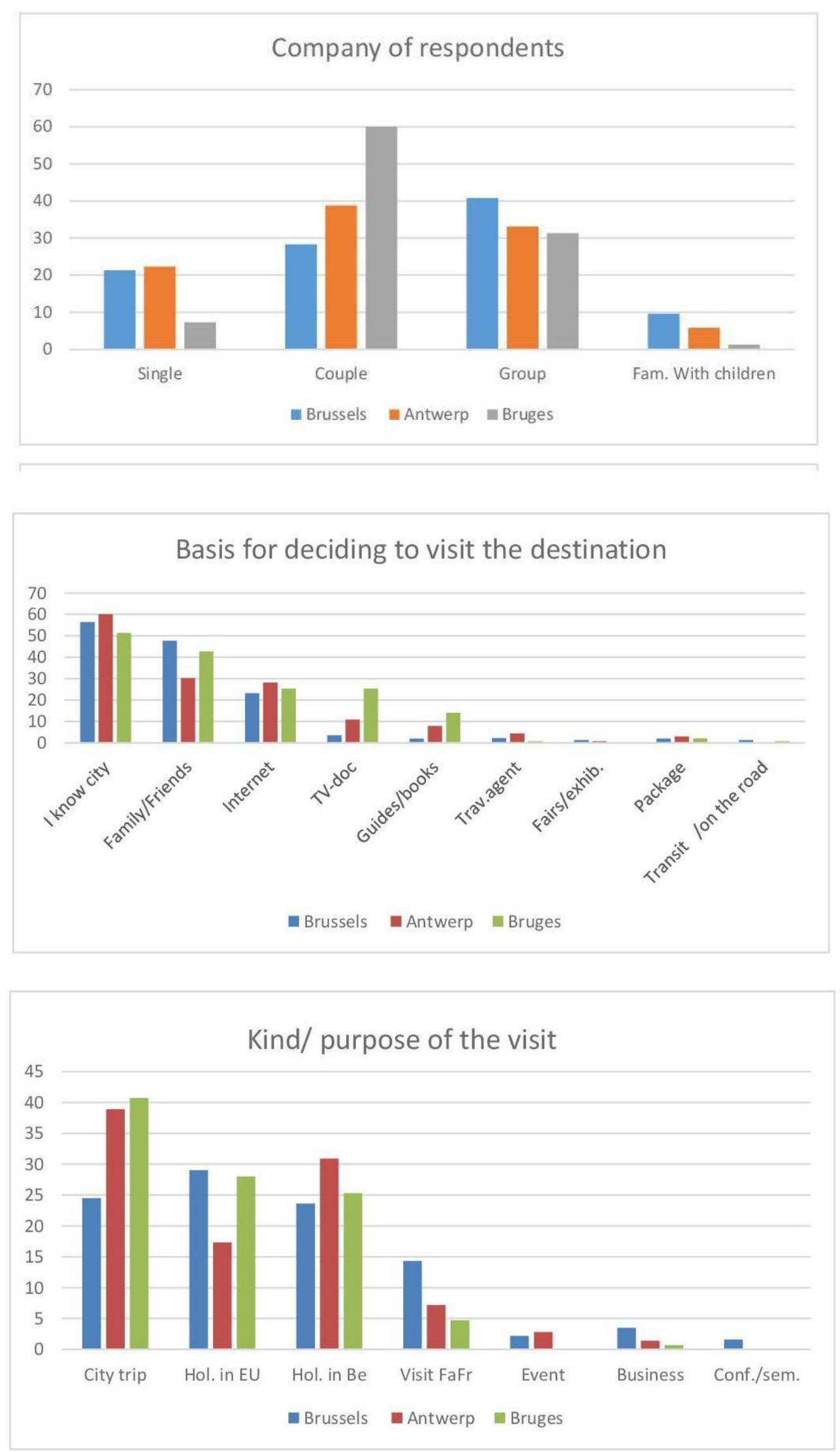


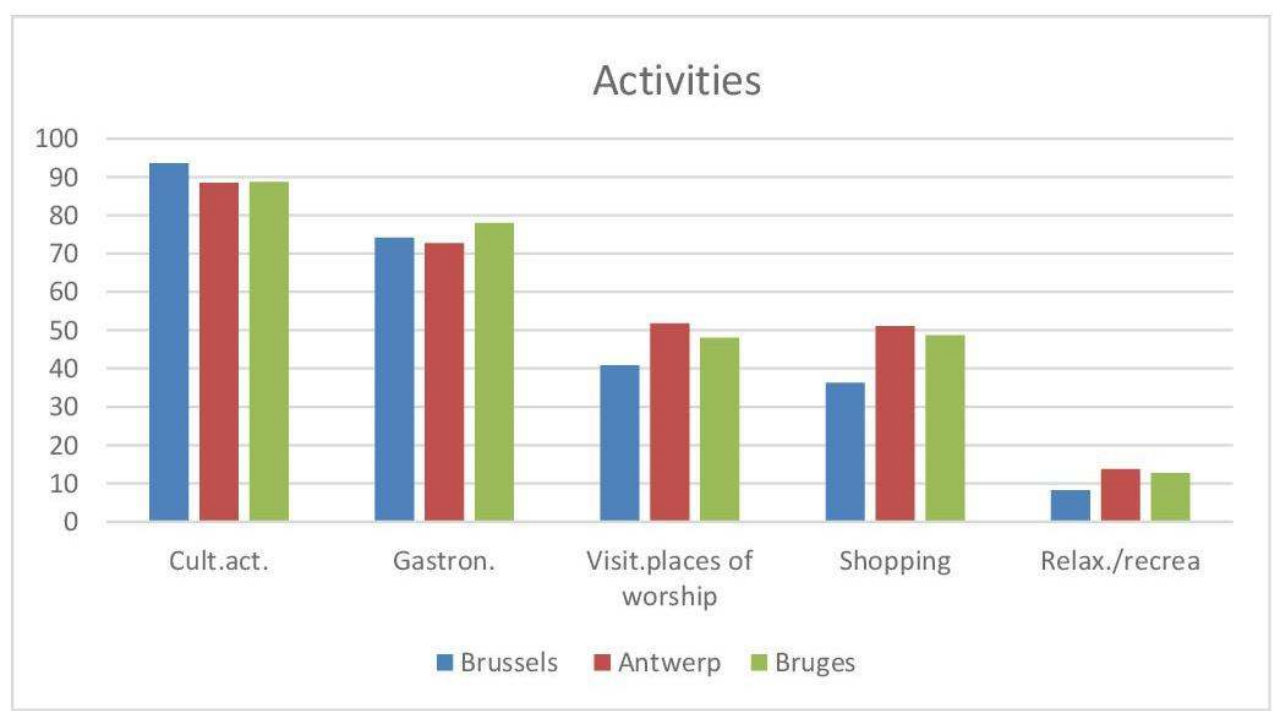

From these profiles, we learn that the profile of the visitors' samples in the 3 cities is quite similar except for Bruges where less singles and considerably more couples were interviewed.

This survey is able to expose the attitude on the spot as well as motives, interpretations and presence versus lack of doubts before making a travel decision of those visitors who decided in favor of a visit. What we do not cover with this survey are the motivation and interpretation of those who finally decided against a visit. This is why the figures on arrivals and overnight stays comparing the situations before and after the attacks are very important as well.

\section{The effects of the attacks on the Belgian tourism industry}

\section{Some indicators as a problem setting}

Data on arrivals, more in particular, arrivals at Brussels Airport are relevant in that respect. This airport is not only the gate to Brussels but it was hit by the attacks in a way that operations were impossible or hindered. For some weeks, all air traffic was diverted towards regional airports in Belgium (Liège, Charleroi, Antwerp and Ostend) as well as airports in neighboring countries situated near the borders such as Lille in France. Gradually, the number of flights that could leave from Brussels Airport increased and from June 30 onwards, the airport was fully operational again, which is quite fast taking into account that the airport suffered from a lot of damage on the infrastructure.

Therefore, it is not surprising, as can be seen from Figure 2, that the number of (departing and arriving) passengers was heavily affected, especially in April 2016 but a quick recovery can be detected. From July onwards one can estimate the real impact on travelers' attitude towards travelling to Belgium/ Brussels. The number of arriving passengers seem recovered from November 2016 onwards. 
Figure 2. Arriving passengers at Brussels Airport $(2015,2016,2017)$.

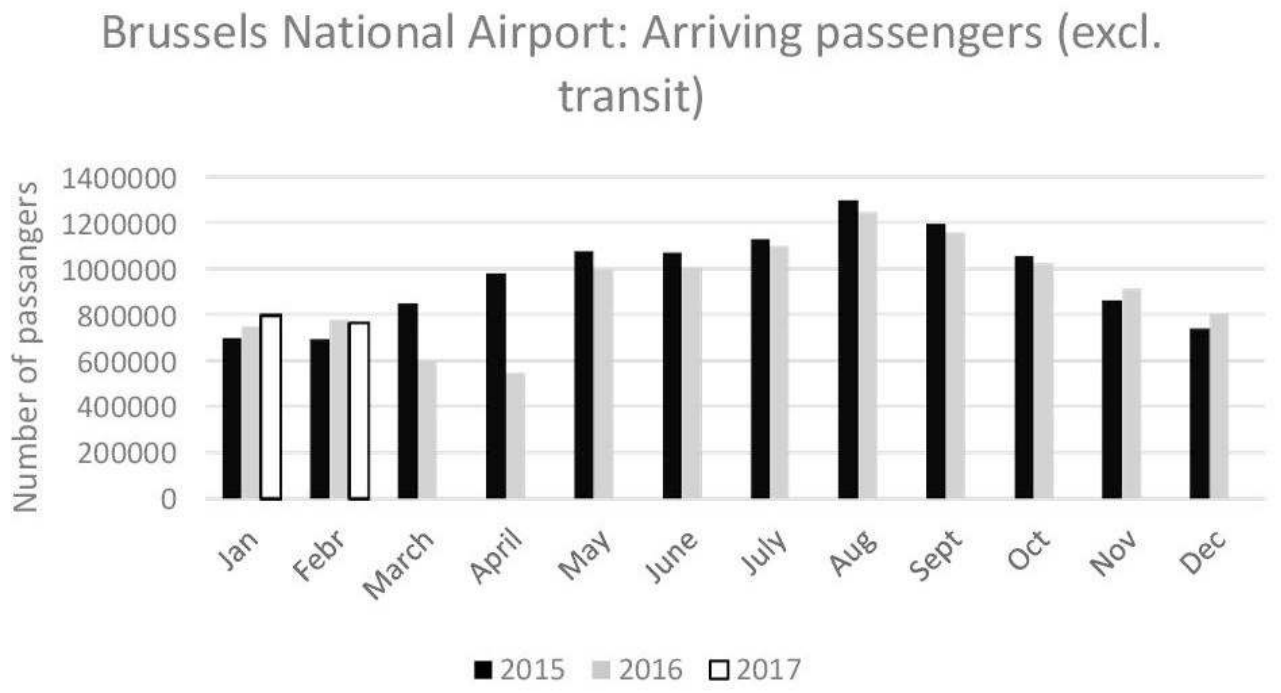

Source : Brussels National Airport (http://www.brusselsairport.be/nl/corporate/statistics) destination sensu stricto (in casu, Brussels) but the whole country which is associated with it. The table shows figures for the four most important countries of origin (the Netherlands, Germany, France and the UK ${ }^{5}$ ) but extended statistics (not represented here ${ }^{6}$ ) show a decrease for all nationalities welcomed in Belgium.

Table 1. Overnight stays in Belgium and the Belgian regions: evolution 2015-2016 (first 6 and 9 months).

\begin{tabular}{|c|c|c|c|c|c|c|c|c|}
\hline \multirow[t]{2}{*}{ Destination } & \multicolumn{2}{|c|}{ Belgium } & \multicolumn{2}{|c|}{$\begin{array}{l}\text { Brussels } \\
\text { (region) }\end{array}$} & \multicolumn{2}{|c|}{$\begin{array}{l}\text { Flanders } \\
\text { (region) }\end{array}$} & \multicolumn{2}{|c|}{$\begin{array}{l}\text { Wallonia } \\
\text { (region) }\end{array}$} \\
\hline & $6 \mathrm{~m}$ & $9 \mathrm{~m}$ & $6 \mathrm{~m}$ & $9 \mathrm{~m}$ & $6 \mathrm{~m}$ & $9 \mathrm{~m}$ & $6 \mathrm{~m}$ & $9 \mathrm{~m}$ \\
\hline Total & $-6,4$ & $-5,2$ & $-22,4$ & $-24,3$ & $-3,5$ & $-2,9$ & $-0,4$ & $+2,8$ \\
\hline $\begin{array}{l}\begin{array}{l}\text { Country of origin of } \\
\text { visitors }^{7}\end{array} \\
\end{array}$ & & & & & & & & \\
\hline
\end{tabular}




\begin{tabular}{|l|l|l|l|l|l|l|l|l|}
\hline Belgium & $-\mathbf{1 , 0}$ & $+1,3$ & $\mathbf{- 1 6 , 1}$ & $-15,7$ & $-\mathbf{0 , 9}$ & $+0,9$ & $\mathbf{+ 4 , 2}$ & $+7,9$ \\
\hline Abroad & $-\mathbf{1 1 , 5}$ & $-12,1$ & $\mathbf{- 2 3 , 9}$ & $-26,3$ & $\mathbf{- 6 , 7}$ & $-8,3$ & $\mathbf{- 4 , 4}$ & $-3,0$ \\
\hline The Netherlands & $-\mathbf{2 , 2}$ & $-2,6$ & $\mathbf{- 1 9 , 0}$ & $-22,4$ & $\mathbf{- 1 , 3}$ & $-4,1$ & $\mathbf{- 0 , 4}$ & $+2,8$ \\
\hline Germany & $\mathbf{- 1 1 , 1}$ & $-12,7$ & $-\mathbf{3 3 , 3}$ & $-35,0$ & $\mathbf{- 6 , 4}$ & $-8,8$ & $+\mathbf{3 , 4}$ & $+1,0$ \\
\hline France & $\mathbf{- 1 4 , 8}$ & $-14,5$ & $\mathbf{- 2 6 , 3}$ & $-23,8$ & $\mathbf{- 1 1 , 2}$ & $-11,6$ & $\mathbf{- 8 , 3}$ & $-10,0$ \\
\hline UK & $\mathbf{- 1 8 , 6}$ & $-20,5$ & $\mathbf{- 2 4 , 0}$ & $-26,6$ & $\mathbf{- 1 6 , 9}$ & $-19,0$ & $\mathbf{- 1 4 , 6}$ & $-15,8$ \\
\hline
\end{tabular}

6M = FIRST 6 MONTHS OF 2016 COMPARED WITH THE FIRST 6 MONTHS OF 2015 6M = fIRST 9 MONTHS OF 2016 COMPARED WITH THE FIRST 9 MONTHS OF 2015

Source: Flemish Tourism Board, based on data FPS Economy Directorate-General Statistics. First 6 months: retrieved 1/10/2016; First 9 months: retrieved 1/3/2017 from http:// www.toerismevlaanderen.be/sites/toerismevlaanderen.be/files/assets/documents_KENNIS/cijfers/ Voorlopige\%20cijfers/2016_Tabellen-9m.pdf

When comparing the situation between the first 6 months and the first 9 months of 2016 (Table 1), the situation seems to improve for the whole of the country due to minor losses in Flanders and growth in Wallonia that seems not to have suffered much from the attacks. The decline of the figures for 2016, compared to those for 2015 are especially due to the situation in Brussels which didn't improve, at least not up to the date we have comparable figures $^{8}$. In line with the expectations, the decline is much higher among foreign visitors than visitors from Belgian origin. For sure, many foreign visitors associate Belgium with Brussels and transfer the perceived unsafety in Brussels to the whole of Belgium. Of course, the damage to the airport hindered not only arrivals with Brussels as a destination but also for destinations in other parts of the country, but visitors from the most important countries of origin do not rely on plains to come to Belgium.

Figure 3 shows that domestic tourism starts recovering (long) before an improvement of international tourism can be detected. One can expect that foreign visitors distrust the situation in Brussels and, to a lesser extent in Flanders, while regaining confidence in Wallonia as a destination. The latter can be explained by the fact that Flanders receives more international tourists than Wallonia (see Annex 1) and is characterized by more urban tourism (tourism to the so called 'Art Cities').

From Figure 4, we can learn that not all countries (markets) of origin react in the same way. The reaction by visitors from the Netherlands was more 'moderate' than by visitors from UK or France. We see already a kind of hesitation before the attacks took place. It is known that visitors from the UK and from non-European countries started cancelling reservations in Belgium after the attacks in Paris (2015); this is even before the attacks in Brussels took place. We may not forget that the measures taken in Brussels, in search for those responsible for the Paris attacks, were big news around the world as well ${ }^{9}$. 
Figure 3. Overnight stays in the Brussels and Flemish regions: evolution between 2015 and 2016 (first 9 months).

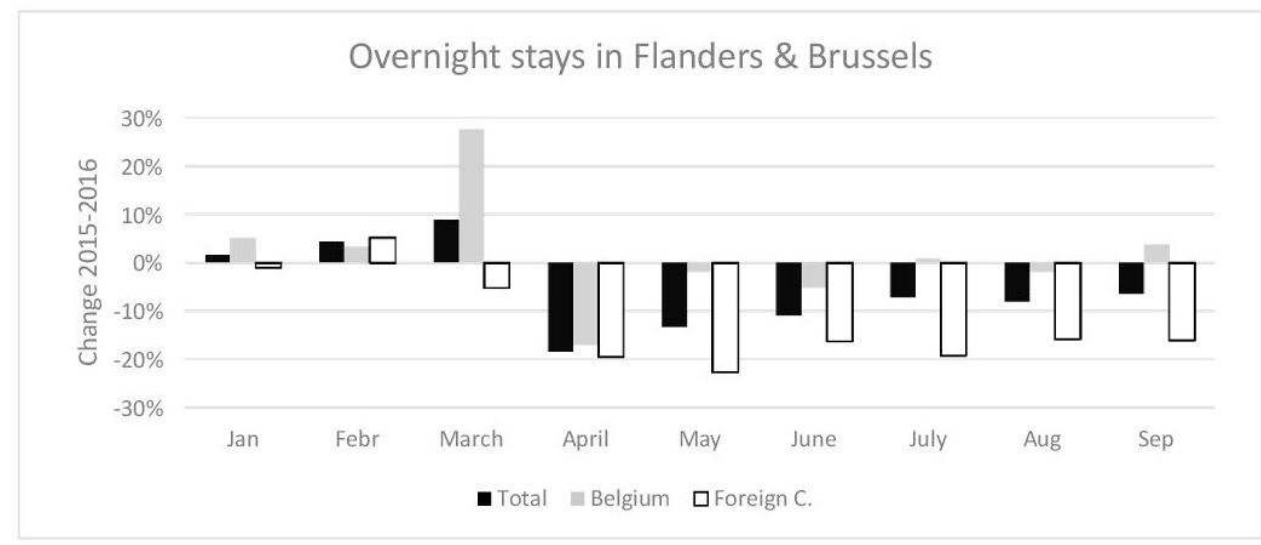

Source: Flemish Tourism Board, based on data FPS Economy Directorate-General Statistics, http:// www.toerismevlaanderen.be/sites/toerismevlaanderen.be/files/assets/documents_KENNIS/cijfers/ Voorlopige\%20cijfers/2016_Summary-9m-ENG.pdf

Figure 4. Overnight stays in the Brussels and Flemish regions by visitors from the Netherlands, Germany, France or the UK: evolution between 2015 and 2016 (first 9 months).

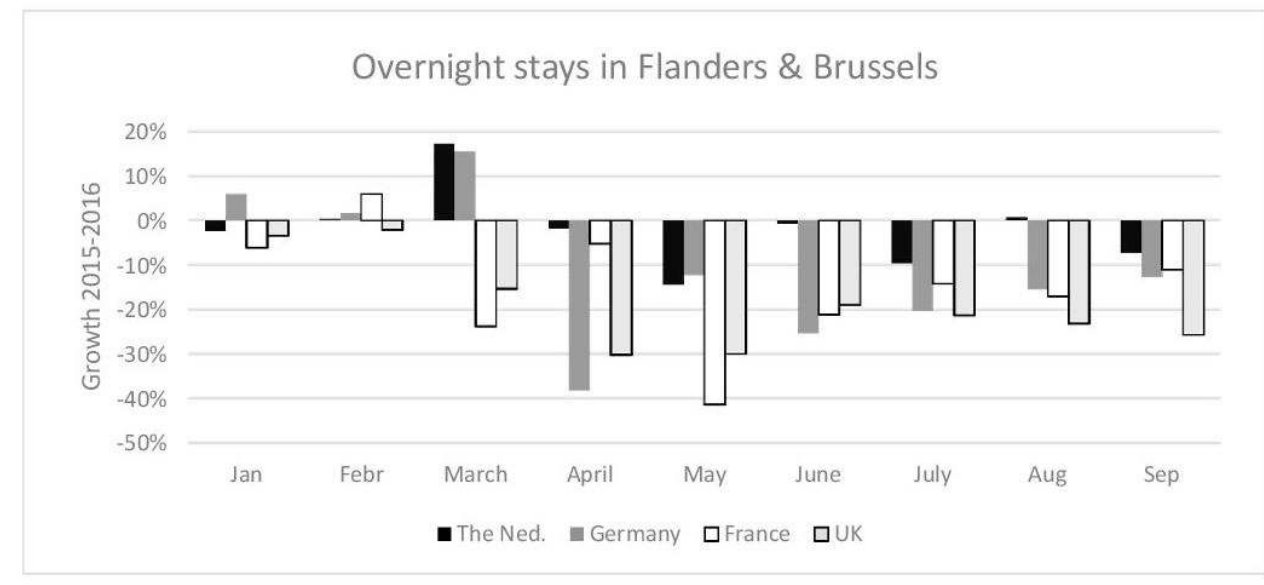

Source: Flemish Tourism Board, based on data FPS Economy Directorate-General Statistics, http:// www.toerismevlaanderen.be/sites/toerismevlaanderen.be/files/assets/documents_KENNIS/cijfers/ Voorlopige\%20cijfers/2016_Summary-9m-ENG.pdf

31 Finally we have a look at the occupancy rate of hotels. The results are clear: for Brussels 2016 was a very difficult year with a decline in occupancy rates. Only from November 2016 onwards one gets 'out of the red' which means that one gains in occupancy rate, compared with the year before (Figure 5). This is less positive than at first sight can be expected since the months November and December 2015 were problematic as well due to the attacks in Paris in November 2015. 
Figure 5: Occupancy rate of hotels in Brussels: 2014, 2015 and 2016.

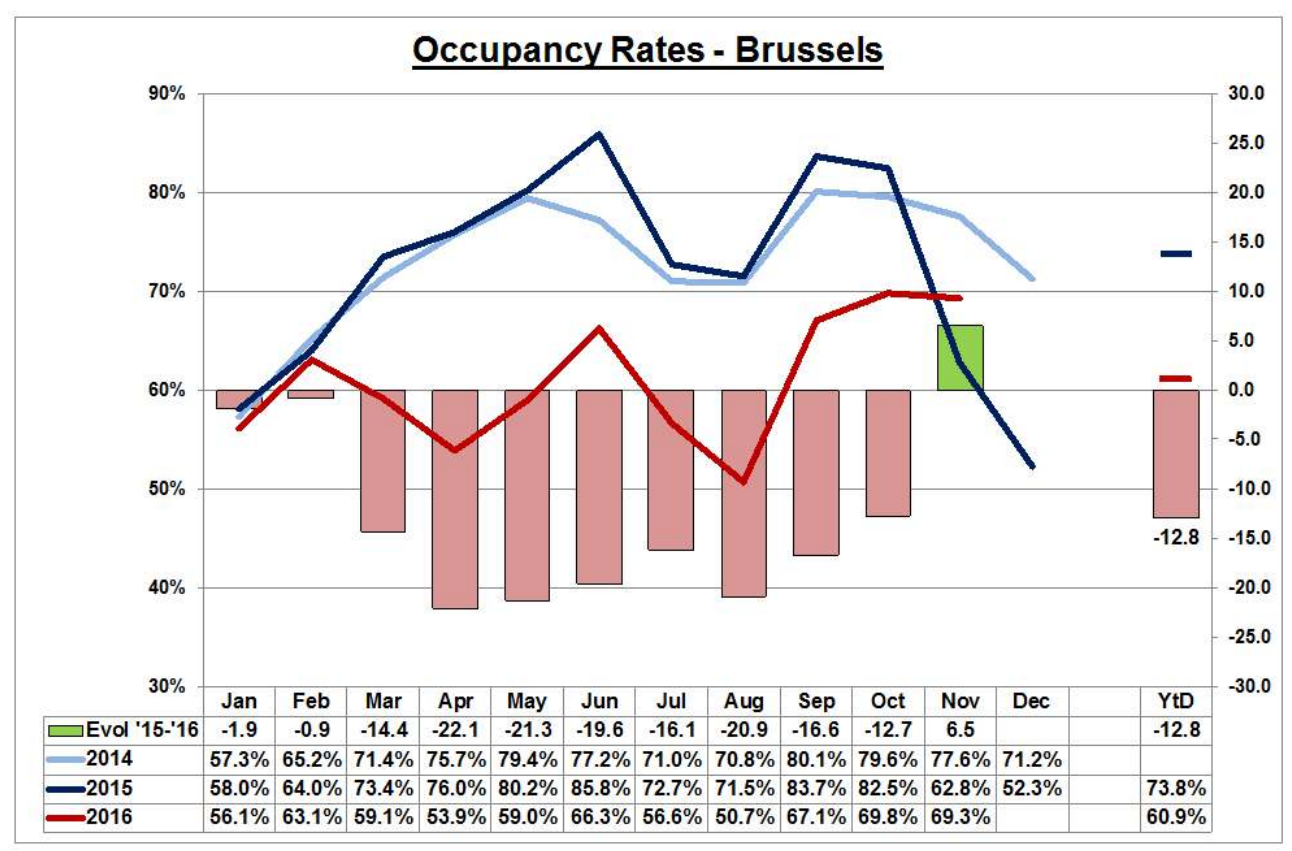

Source: Observatorium voor Toerisme te Brussel: Hotelbarometer, https://visit.brussels/binaries/ content/assets/pdf/baro_hotel_11_2016_nl_extr.pdf, retrieved 1/3/2017

To round up this statistical overview, we present the occupancy rates in our benchmark cities Antwerp and Bruges. In principle, there were no attacks in Antwerp nor in Bruges but one can expect that this affected the hotel industry in cities beyond Brussels as well, partly because they may depend on transportation via Brussels Airport but -hypothesisbecause they are covered by the label 'Belgium' as well. Figure 6 reveals that Bruges was more heavily hit than Antwerp, probably because of its tourism dedication, with a high importance of distant international markets while Antwerp has a much more diversified economy, not depending on tourism to the same degree as Bruges. But, Bruges seemed to enjoy full recovery by the end of 2016 while Antwerp followed at a distance. Indeed, the occupancy rate of Antwerp in January 2017 (62\%) is higher than the occupancy rates of January 2016 (55\%) and January 2015 (58\%). Taking into account that many reservations are made quite far in advance ${ }^{10}$, it is surprising that numbers recover that quickly. 
Figure 6. Occupancy rate of hotels in Antwerp and Bruges: 2015 and 2016.
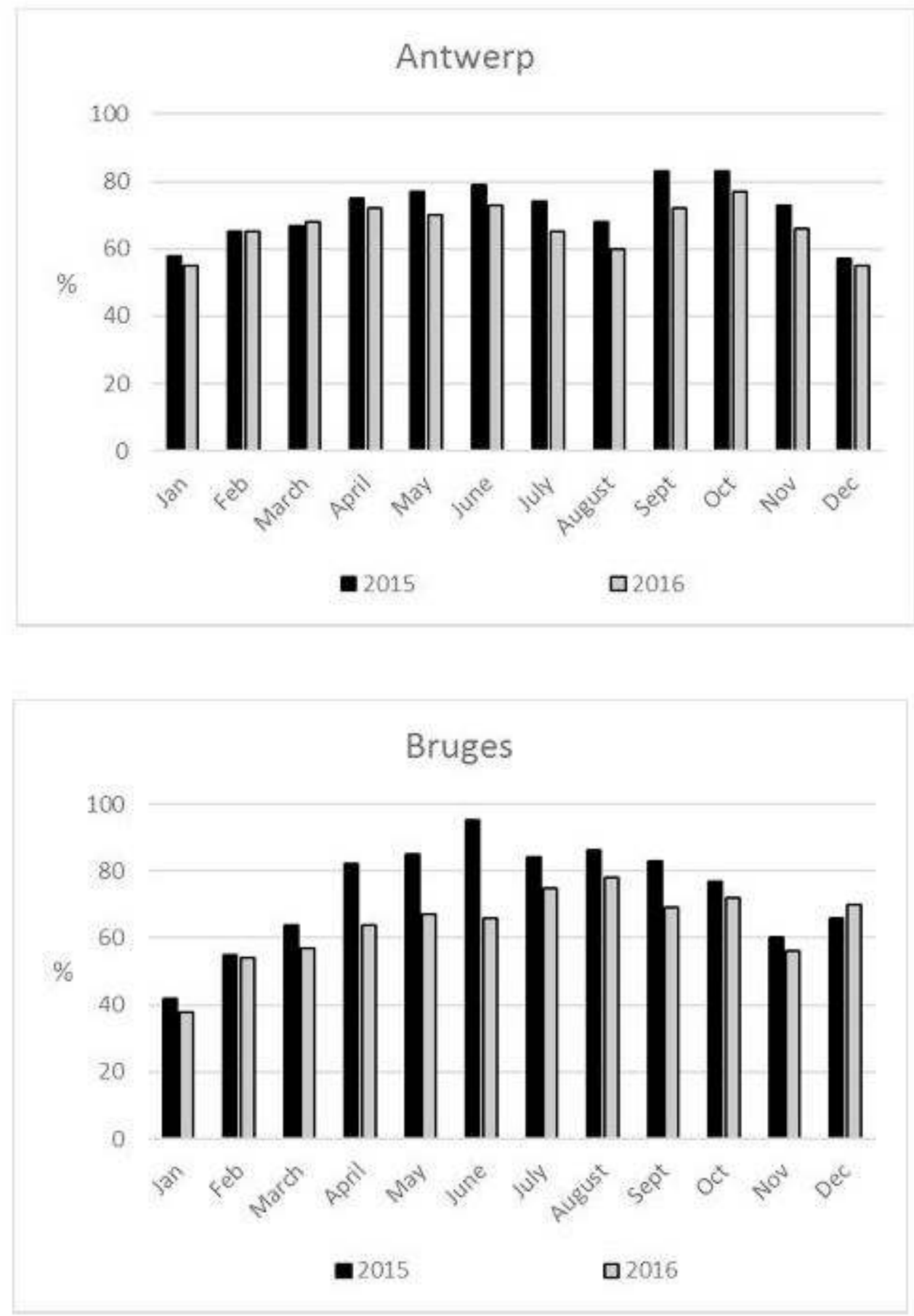

SOURCE: TOURISM BOARD OF FLANDERS (TOERISME VLAANDEREN), HOTEL BAROMETER, TOURISM DATABASE, DATA EXTRACTED AT 1/3/2017

In general the statistics show a decline of the number of overnight stays and arrivals which means that some tourists are scared away but we can detect a recovery within half a year. This is in line with the findings of the World Economic Forum that economies recover quickly after an attack ${ }^{11}$. Of course 'economies' which are characterized by a large 
number of imperative and compulsory contacts, are not comparable with economies dominated by tourism which implies more movements based on free decision making (e.g. in a context of leisure). Another reasoning might be applicable as well: business meetings and consultation can be held e.g. by skype while for an authentic tourism experience, there is hardly any other choice than to visit the destination. The figures point out that even places where attacks do not take place, are affected.

Therefore, in the following section we will frame more precisely what elements can influence a tourist's attitude towards destinations hit by events that are related to violence as well as tourist's behavior on the spot. In a further section we will attempt i) to measure the level of safety tourists experience in Brussels and in two other, well visited cities in Belgium and ii) if they change or adapt their behavior during their stay.

\section{Attitudes and perceptions}

It became clear that simple statistics revealed already a lot of information. Therefore, we start with a number of graphs focusing on the matter: 'safety and security'.

Our results reveal that, after ca. half a year, all visitors are still very much aware of the events of March 22, 2016 (Figure 7). Therefore, the combination of the information in Figure 7 and 8 is somewhat surprising. On the one hand, visitors are very well informed about the attacks. $97 \%$ (Brussels) to $99 \%$ (Bruges) knew about the attacks while most of the visitors in Brussels could recall one or both places under attack. On the other hand, ease is reflected by the fact that the majority of the international visitors on the spot didn't even ask for or look up travel advice. As mentioned before, it is not possible to comment on the attitude of those (potential) visitors who choose, consciously or not, another destination.

Figure 7. Share of visitors showing awareness of the terrorist attacks in Brussels on March, 2016.

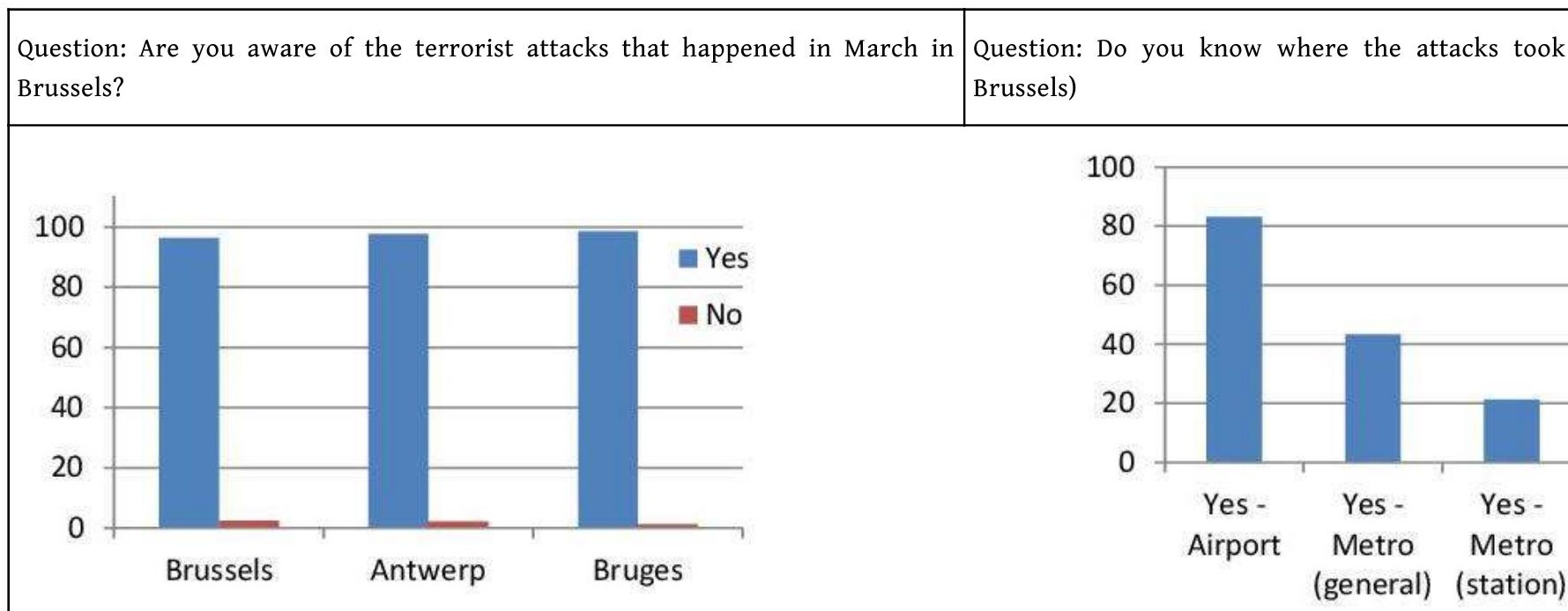

SOURCE: OWN SURVEY, 2016 
Figure 8. Share of international visitors who searched for travel advice on Belgium/Brussels.

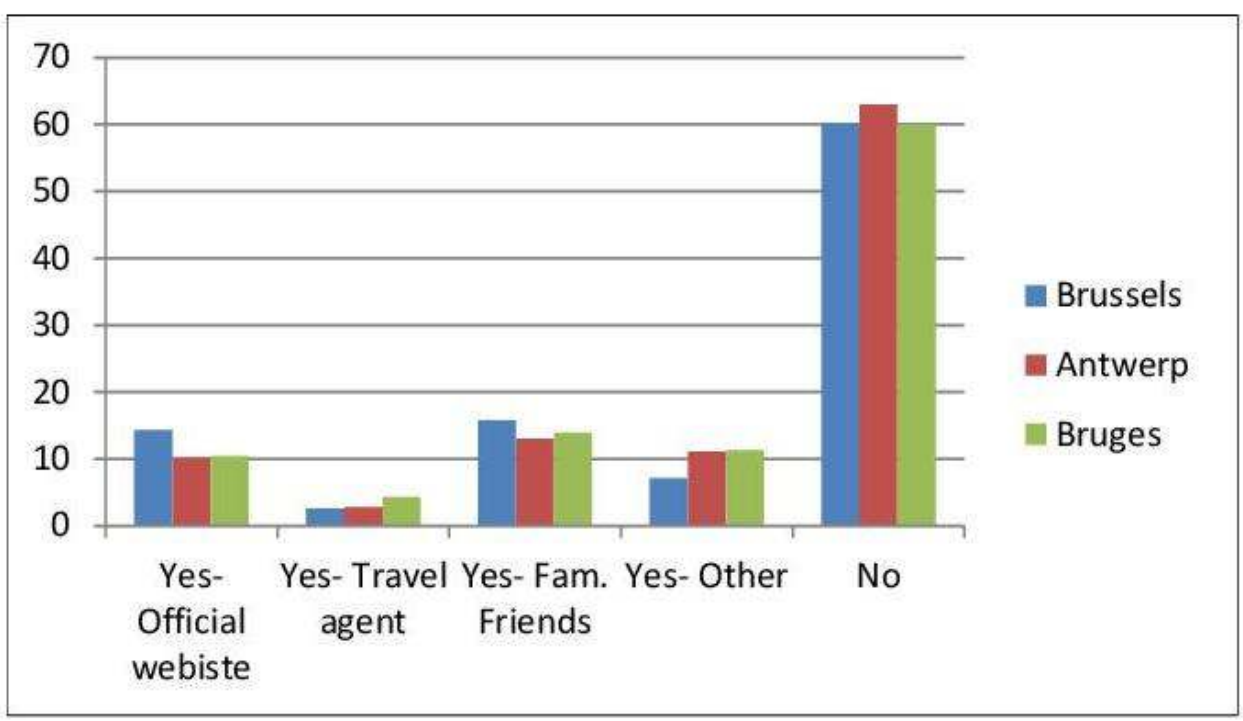

SOURCE: OWN SURVEY, 2016

Figure 9 reveals that visitors feel very safe indeed. They feel safer in Bruges than in Brussels or Antwerp but this does not imply that they feel unsafe, on the contrary. In fact the mode and median for 'Feeling safe' in Brussels and Antwerp is 8 (on 10) while, in Bruges, we obtain a 9 (on 10). When asked if the (local) authorities took appropriate measures, we get a reverse situation; again one considers the situation for Brussels and Antwerp very much OK (mode and median $=8$ on 10) while, for Bruges, the median is only 7 (on 10). It is interesting to notice that this might have to do with the number of military on the streets (correlation of 0.513 between appropriate measures and presence of military). In Brussels and Antwerp, their presence is much more prominent than in Bruges which might explain the difference. Further, the questionnaire might have been somewhat suggestive at that point since a question about the presence of military leading to more safety was asked just before the question on appropriate measures. Although the graphs look very much alike for the three cities, a test reveals that there is a (statistically) significant difference between Brussels and Bruges as far as feelings of safety are concerned (not for appropriate measures) while this is not the case for Antwerp (no statistically significant difference between Brussels and Antwerp).

Figure 9 . Feelings of safety $\&$ opinion on safety measures (\% respondents).

- Question: How safe do you feel in Brussels on a scale of 1 to 10 ? 


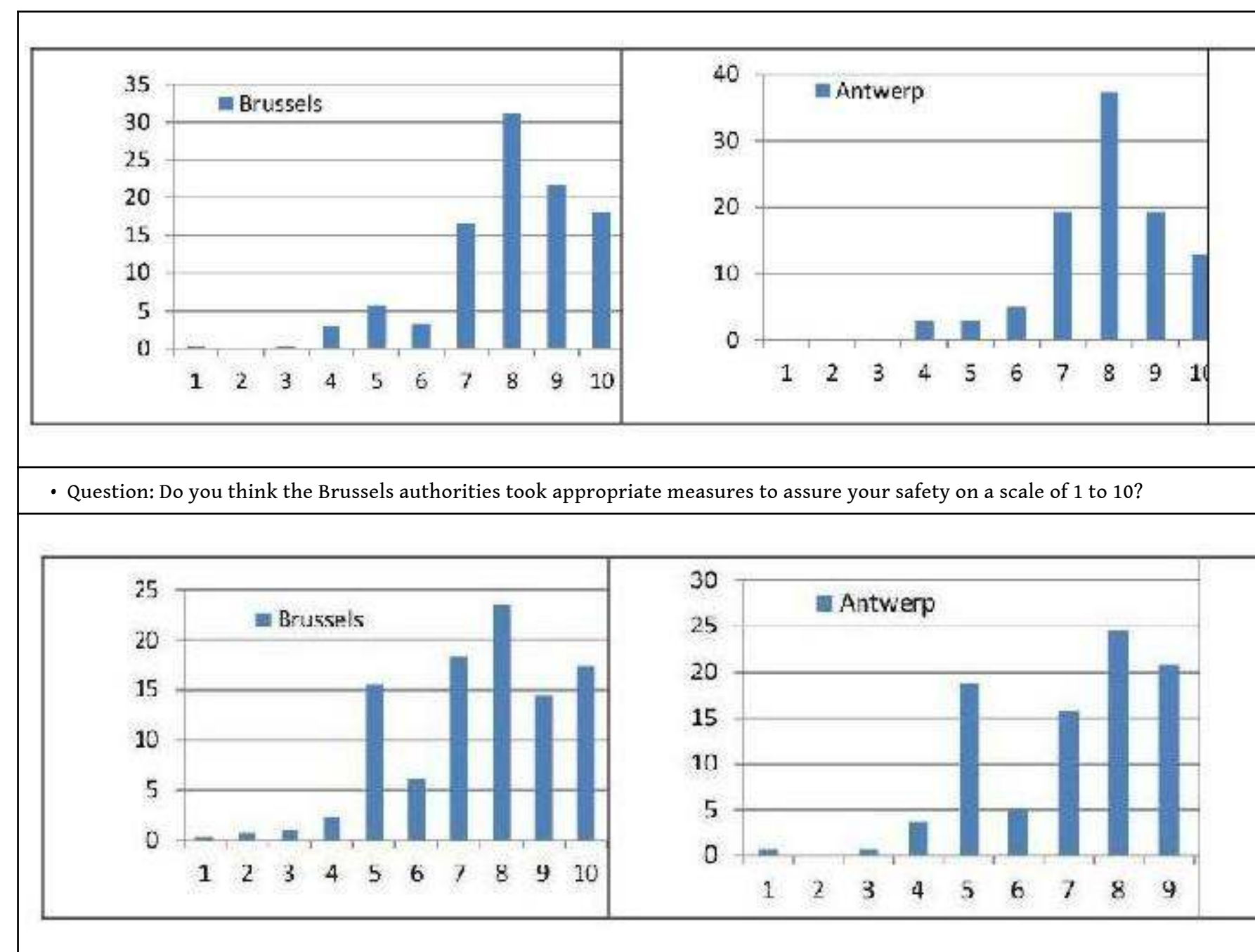

SOURCE: OWN SURVEY, 2016

When asked about the influence on several aspects of behavior, the large majority does not mention a specific kind of adapted behavior. For sure the percentages are higher in Brussels than in the benchmark cities but even in Brussels, the number of people and the share of people within our sample, are limited. The most important percentage is on the question if people try to avoid places where the attacks took place. Especially in Brussels, 67 people or $21 \%$ of our sample tried to avoid those places.

\section{Table 2. Share of respondents who agree on changed behavior because of the terrorist attacks}

\begin{tabular}{|c|c|c|c|}
\hline Question from the questionnaire & $\begin{array}{c}\text { Brussels/ } \\
\text { yes }\end{array}$ & $\begin{array}{c}\text { Antwerp/ } \\
\text { yes }\end{array}$ & $\begin{array}{c}\text { Bruges/ } \\
\text { yes }\end{array}$ \\
\hline Did these attacks influence your plans to visit/stay in Belgium & 4,1 & 5 & 2,7 \\
\hline Did these attacks influence your plans to visit/stay in Brussels/Antwerp/Bruges & 6,1 & 1,4 & 0 \\
\hline Did these attacks influence the number of days/nights/hours that you are planning to stay in Brussels/Antwerp/Bruges? & 0,6 & 0,7 & 0 \\
\hline Did these attacks influence the kind of places you are planning to visit in Brussels/Antwerp/Bruges? & 5,7 & 0,7 & 0,7 \\
\hline Did these attacks influence the way you travel from home to Brussels/Antwerp/Bruges (train, bus, car, plane)? & 3,2 & 0 & 0 \\
\hline Did these attacks influence the way you travel around in the city (foot, metro, bus, taxi...)? & 6,7 & 0 & 0 \\
\hline Do you try to avoid the places where the attacks took place? & 21,3 & 7,2 & 8,7 \\
\hline
\end{tabular}

SOURCE: OWN SURVEY, 2016

Most of the questions above asked for additional information via an open question, insisting on 'how' or 'why'. What we can learn is that some visitors did not feel 
comfortable although they did not take action by changing their behavior, not as much because of the place but because of the people: "everybody is strange to me". Actions taken, can be divided in actions that have to do with transportation and actions that are related to the use of space in the city. The former implies being more cautious on trains, not to take public transportation in general and the metro in particular, to avoid planes as well as changing airports. As for the latter, people mentioned that they avoided "places where people tend to gather", "large crowds and public events" such as "the flower carpet on the Grand Place (15/8)", "places that could be a target such as Belga cafe", "the European area" or "the Mediterranean market near Midi station". Finally a respondent mentioned that he was only walking during daytime while a couple mentioned that they shifted part of their stay to Bruges.

We analyzed the visitors' sample for Brussels more in depth to discover some pared relationships. From the 195 relations that were investigated (via cross table analysis) only 28 were significant on a 95\% confidence level. The most remarkable are the following:

- Visitors who came to Brussels for 'Visiting family and friends' (as a main motivation), did ask their family and/or friend for advice while the places they visited, were influenced by the events; we didn't see the same behavior among visitors who took e.g. a city trip;

- Visitors with 'shopping' as a main activity, did consult the official website and/or family and friends for travel advice while the places they visited, were influenced by the events; they had a lower feeling of safety as well; this was not at all the case for visitors who visited Brussels for cultural reasons; those visiting Brussels for cultural activities did adapt their way of travelling through the city;

- People who gathered travel advise by consulting official websites, had a lesser feeling that the measures taken were satisfactory; this was not at all the case for people who knew the city already before;

- People who arrived by plane at Brussels Airport seemed to be (even) more aware of the attacks than others (although everyone was highly aware of them) and looked up travel advice on official websites but their safety feeling was not different than for those who did not travel by plane. Further, car users showed a different attitude towards the presence of military than visitors who used other means of transportation: the presence of military did not improve their feeling of safety as this was the case for non-car users;

- As for the company or party, those travelling alone indicate that the attacks did influence their plans for Belgium as well as for Brussels, while groups indicate significantly more that the attacks did not change their plan; the latter shows that company can be interpreted as an indicator of vulnerability versus robusticity (see also Table 3);

- Nationalities were aggregated in 'proximity groups', according to the distance from the country of origin to Belgium which might imply a cultural distance as well (Belgium, neighboring countries, rest EU, non-EU; see also Table 3); it is interesting to notice that the closer the origin of the visitors, the more travel plans were influenced, at least for Brussels as a destination, while this is not significant for Belgium; visitors from further away did ask more for travel advice via official website but were less influenced in terms of visited places than visitors from nearby origins; further, people from far away were more convinced that the Brussels authorities had taken appropriate measures than people from nearby destinations;

- Finally, older age did influence a number of elements such as: more travel advice from official websites, more influenced in terms of plans to visit/stay in Belgium, more influenced in terms of visited places and way of travelling through the city than younger visitors but 
they didn't experience other feelings of safety. No such a differentiation could be found for gender.

41 Since the number of visitors who experienced a low degree of safety (see Figure 9) and changed their behavior accordingly (Table 2), is low, there was no point for further analysis on the differentiation within this group. Finally, we tried to test if some profiles could be detected among the visitors, bringing characteristics of visitors in line with their feelings of safety, by using a selection of (mainly numerical and ordinal) variables in a multivariate analysis (PCA).

The results can be found in Table 3. In fact, this table shows that the feelings of safety constitute an important package of information from our research but it is very difficult to link these elements with particular characteristics of the visitors. Further the information shows two distinct groups: a group of rather young visitors who originate from rather far away and came to Brussels for the first time versus older, repeat visitors characterized by a less 'robust' company or party (alone or couple) which means that they are more vulnerable in case something would happen because they are less integrated in a group. None of these two profiles are clearly linked with a specific 'feeling of safety' variable though.

Table 3. PCA scores (rotated factor loadings)

\begin{tabular}{|l|l|l|l|}
\hline & Component 1 & Component 2 & Component 3 \\
\hline eigenvalue & 1.927 & 1.588 & 1.174 \\
\hline \% variance & $24 \%$ & $20 \%$ & $16 \%$ \\
\hline Variables & & & \\
\hline Age & & -0.535 & 0.558 \\
\hline Company-Robusticity & & & -0.569 \\
\hline Distance from origin & & 0.817 & \\
\hline Length of stay & & & 0.705 \\
\hline \# visits (1st/ repeat) & & -0.716 & \\
\hline Feeling of safety* & 0.714 & & \\
\hline Presence of military* & 0.792 & & \\
\hline Appropriate measures* & 0.832 & & \\
\hline
\end{tabular}

*LIKERT SCALE 1 TO 10; SOURCE: OWN SURVEY, 2016 


\section{Discussion and conclusions}

43

The results presented above represent bad and good news for the tourism industry in Brussels and Belgium and for Brussels/Belgium as a destination.

The bad news is that terrorist attacks do not pass unnoticed, on the contrary. They have an effect on the visitors' behavior in terms of arrivals and overnight stays (with effects on e.g. hotel occupancy) for several months. In fact, it took Brussels more than six months to recover. Research in the past revealed that effects of decline in tourism demand lasted from one to six months, with a recovery in approximately $50 \%$ of the destinations within three months or less (Pizam and Smith, 2000). Pizam and Fleischer (2002) mention a period of six to twelve months to recover. Of course, all cases with bodily harm or death, have a longer effect on tourism demand than those with only material damage. Therefore, the recovery of Brussels (with a double attack at which 32 people were killed and ca. 300 injured) is in line with findings for other affected destinations. The difference between visitors originating from other parts of Belgium and from abroad is not a surprise. Earlier research revealed that local residents are much less sensitive to risk than international tourists (Yechiam et al. 2005). This means that, in times of crisis, different policies should be developed concerning international and domestic tourism but also that, in case of Belgium, visitors from the Netherlands behave more like locals. Information might be the main explanatory factor. Since Flanders (northern part of Belgium) and the Netherlands speak the same language, one can expect that Dutch people are better informed about the political events in Belgium than other international tourists. Nevertheless this seems not applicable to the relationship Wallonia-France which share the language as well. Several other elements can be suggested such as a higher opportunity cost to avoid a big international city for Dutch (small country) than for French people (large country) or personal experience since many Dutch people visited Belgium (Belgian cities) before, without being harmed. Related to that, we should keep in mind that, after a terror chock, willingness to pay declines (about 25\%; Araña and León, 2008) while a change in the structure of consumer preferences occurs, affecting both, the decision to travel and one's preferences for certain attributes of the tourism product. Therefore one can suggest that the willingness to pay by Dutch visitors is less affected than by other nationalities. This pleads for the point of view of Yechiam et al. (2005) that main differences in the impact of terror events are depending on cultural aspects, personal experience and costs of avoiding the risk. In our case, the physical and cultural proximity of the Dutch can explain the difference with other foreign countries of origin and is an important element to bear in mind for future strategies. Further it has been seen that terrorist attacks in one destination can influence the relative position of another destination (Araña and León, 2008). In other words the attacks in Paris (2015) or London (2013) may have influenced the position of Brussels as well, since the label 'Brussels' incorporates a set of attributes that are similar to Paris or London. It's worth reflecting on this as an additional explanatory factor for the difference between visitors from the Netherlands on the one hand and from France or the UK or other countries of origin on the other hand. This is particularly important since Yechiam et al. recommend to reduce the negative effects of (rare) terrorist attacks by focusing on the domestic market "by ensuring that citizens [locals or similar] continue to partake in relatively safe leisure 
activities [...] and spend more time shopping and dining [in the affected place] (2005, pp. 437-438).

We see that the effects are felt far beyond the place that suffered from the attack(s). The more this place is a brand for the region or for the country, the more other sites and destinations

in the country feel the impact as well. This is particularly the case for places/cities in Belgium since Brussels and Belgium are very much associated in the minds of the international community, among others because of the presence of major EU institutions. Therefore a strong and common action at a national level is desirable but the regionalization of Belgium, resulting in an independent tourism policy - and destination management agencies - for the three regions (Flanders, Brussels and Wallonia) makes it difficult to follow some of the principles towards an integrated approach to crisis management in affected tourist destinations as presented by Mansfeld (1999). One of his principles is that the damaged image has to be rehabilitated "based on common and widely accepted messages", while another principle is that "all marketing campaigns aimed at international tourism must be stopped [since] in every home in the generating countries live pictures [of the attacks] are exposed on the TV screens." (Mansfeld, 1999, p. 35).

Although tourists seem to feel safe again on a relatively short term and show clear resilience, some do adapt their behavior which consists of avoiding public transportation and some crowded or well-known places. Therefore it is worth considering the following reflection by Pizam and Smith: "People [...] appear to be willing to consider a place secure again following a terrorist act if proper marketing/image and crisis management occur" (2000:136). To gain insights in what the visitors consider 'proper', we need more and different information, completing aggregate figures and time series, such as individual data on micro-tourist preferences (Araña and León, 2008). Our street survey methodology proofed its relevance by providing information that otherwise would not be available e.g. on elements such as the presence of military on the streets. We learned from our results that visitors associate military very much with safety and right measures taken by public authorities which, in turn, is important in view of the development of adequate crisis management strategies.

Our results are not decisive on a possible effect of self-moderation and avoiding certain places from a safety perspective. In other words, it seems that visitors are not easily scared off, as indicated by the statistics and by the information gathered from our respondents. Nevertheless, attitudes are complex and fear or a feeling of unsafety can stay latent (as one can learn from literature on gender; Jordan and Aitchison, 2008; Khan, 2011; Wilson and Little, 2008). Events such as terrorist attacks can feed a feeling of unsafety that some visitors carry with them, even in 'normal' circumstances. What we know is that feelings of safety result, among others, in a limited way of using space which reduces the tourism experience. Former research (Vanneste and Vandepoel, 2012; Annex 2) shows, for Brussels, that use of public space by visitors is very much related to safety feelings. The fact that some (groups of) visitors indicated that the terrorist attacks influenced the kind of places they planned to visit or visited (survey, Brussels, 2016), is in line with these former findings about safety related use of space (survey, Brussels, 2011). This, in turn, is valuable information for destination developers, certainly in the aftermatch of events such as terrorist attacks.

Further research on the relative effectiveness of different types of policy response, using a modeling approach is recommended since the choice of policy measures should, ideally, 
be based on prior experience and estimations. The implementation of crisis management policies, or at least some measures, proved their effectiveness in reducing effects of terrorist attacks, e.g. after the September 11 events (Blake and Sinclair, 2003). Such measures were taken after the terrorism events in March 2016, as well. We can mention campaigns such as \#shareoursmile (June 2016) which tried to make foreign visitors an ambassador for Belgium as a destination after their visit, or joint promotion campaigns with neighboring countries for Thalys, Eurostar and Deutsche Bahn ${ }^{12}$. Up to now, their impact is not clear and deserves more attention.

\section{BIBLIOGRAPHY}

ALBU C.E. (2016), Tourism and Terrorism: a Worldwide Perspective, CES Working Papers, VIII, I, pp. 1-19, http://ceswp.uaic.ro/articles/CESWP2016_VIII1_ALB.pdf.

AZIZ H. (1995), Understanding attacks on tourists in Egypt, Tourism Management, 16, 2, pp. 91-95.

ARAÑA J.E., LEÓN C.J. (2008), “The Impact of Terrorism on Tourism Demand”, Annals of Tourism Research, 35, 2, pp. 299-315.

BLAKE A., SINCLAIR M.T. (2003), “Tourism Crisis Management. US Response to September 11”, Annals of Tourism Research, 30, 4, pp. 813-832.

BURNS P.M., LESTER J.A. \& BIBBINGS L. (eds.) (2010), Tourism and Visual Culture. Volume 2 Methods and Cases, Wallingford (UK)/Cambridge (USA), CABI.

BUTLER R.W. (1990), “The influence of the Media in Shaping International Tourist Patterns”, Tourism Recreation Research, 15, 2, pp. 46-53.

CAVLEK N. (2002), "Tour operators and destination safety", Annals of Tourism Research, 29, 2, pp. 478-496.

CHANDLER J. (1991), “How Safe Are Our Airports?”, Travel and Leisure, 21, 5, pp. 94-100.

CRENSHAW M., LAFEE G. (2017), Countering Terrorism, Washington DC, Bookings Institution Press.

EDKINS S., PIN-FAT V. \& SHAPIRO M.J. (2004), Sovereign Lives: Power in Global Politics, New York, Routledge.

ENDERS W., SANDLER T. (2002), "Patterns of Transnational Terrorism, 1970-1999, Alternative Time-Series Estimates", International Studies Quarterly, 46, 2, pp. 145-165.

FEICHTINGER G., HARTL R.F., KORT P.M. et al. (2001), “Terrorism Control in the Tourism Industry", Journal of Optimization Theory and Applications, 108, 2, pp. 283-296.

FUCHS G., URIEL N., REICHEL A. \& MAOZ D. (2012), "Vacationing in a Terror-Stricken Destination. Tourists' Risk Perceptions and Rationalizations”, Journal of Travel Research, 52, 2, pp. 182-191.

GANOR B. (2010), “Defining Terrorism - Is One Man's Terrorist Another Man's Freedom Fighter?", ICT's Publications, website International Institute for Counter-Terrorism, https://www.ict.org.il/ Article/1123/Defining-Terrorism-Is-One-Mans-Terrorist-Another-Mans-Freedom-Fighter. 
GOLDMAN O.S., NEUBAUER-SHANI M. (2017), "Does International Tourism Affect Transnational Terrorism?", Journal of Travel Research, 56, 4, pp. 451-467.

GUPTA A. (2011), “Terrorism and its Impact on Financial Performance: A Case of Tourism Industry", International Journal of Financial Management, 1, 4, pp. 46-52.

JORDAN F., AITCHISON C. (2008), “Tourism and the sexualisation of the gaze: solo female tourists' experiences of gendered power, surveillance and embodiment”, Leisure Studies 27, 3, pp. 329-349.

KALIA S. (2009), Impact of Terrorism on Tourism, http://sumedhakalia.wordpress.com/2009/10/25/ impact-of-terrorism-on-tourism (retrieved 1/3/2017).

KAMRAVA M. (2011), The Modern Middle East: A Political History since the First World War, Berkeley, University of California Press.

KEOHANE D. (2005), The EU and counter-terrorism, Working Paper May 2005, London, Centre for European Reform, http://library.coleurope.eu/pdf/CER/keohane.pdf.

KHAN S. (2011), “Gendered leisure: are women more constrained in travel for leisure?”, Tourismos: an international multidisciplinary journal of tourism, 6, 1, pp. 105-121.

KORSTANJE M.E. (2013), “Preemption and terrorism. When the future governs”, Cultura, 10, 1, pp. 167-184.

LARSEN S., BRUN W. \& OGAARD T. (2009), "What tourists worry about. Construction of a scale measuring tourist worries", Tourism Management, 30, 2, pp. 260-265.

LUTZ B.J., LUTZ J.M. \& WRALSTAD ULMSCHNEIDER G. (2002), “British Trials of Irish Nationalist Defendants: The Quality of Justice Strained”, Studies in Conflict \& Terrorism, 25, 4, pp. 227-244.

LUTZ J.M., LUTZ B.J. (2009), “How Successful Is Terrorism?”, Forum on Public Policy, https:// www.researchgate.net/profile/James_Lutz3/

publication/46293279_How_Successful_Is_Terrorism/links/5450ef0a0cf24e8f7376ac59.pdf.

MANSFELD Y. (1999), “Cycles of War, Terror, and Peace: Determinants and Management of Crisis and Recovery of the Israeli Tourism, Industry", Journal of Travel Research, 38, pp. 30-36.

MCGUCKIN M., DEMICK D. (2000), “Northern Ireland's image - Platform or Pitfall for gaining the competitive edge", in RUDDY J., FLANAGAN S. (eds.), Tourism Destinations: Gaining the Competitive Edge, Dublin, Tourism Research Centre, Dublin Institute of Technology, pp. 335-343.

PIZAM A., SMITH G. (2000), “Tourism and terrorism: a quantitative analysis of major terrorist acts and their impact on tourism destinations", Tourism Economics, 6, 2, pp. 123-138.

PIZAM A., FLEISCHER A. (2002), "Severity versus Frequency of Acts of Terrorism: Which Has a Larger Impact on Tourism Demand?", Journal of Travel Research, 40, 3, pp.337-339.

RANGA M., PRADHAN P. (2014), “Terrorism terrorizes tourism: Indian Tourism effacing myths?”, International Journal of Safety and Security in Tourism, 1, 5, pp. 26-39.

RICHTER L.K. (1983), “Tourism, politics and political science. A case of not so benign neglect”, Annals of Tourism Research, 10, 3, pp.313- 335.

RICHTER L.K., WAUGH W.L. (1986), “Terrorism and tourism as logical companions”, Tourism Management, 7, 4, pp. 230-238.

SEDDIGHI H.R., THEOCHAROUS A.L. (2002), "A model of tourism destination choice: a theoretical and empirical analysis", Tourism Management, 23, 5, pp.475-487.

SÖNMEZ S.F. (1998), "Influence of terrorism risk on foreign tourism decisions", Annals of Tourism Research, 25, 1, pp.112-144. 
SÖNMEZ S.F., GRAEFE A.R. (1998), “Determining Future Travel Behavior from Past Travel Experience and Perceptions of Risk and Safety", Journal of Travel Research, 37, 2, pp.171-177.

SÖNMEZ S.F. (1999), “Tourism in Crisis: Managing the Effects of Terrorism”, Journal of Travel Research, 38, 1, pp.13-18.

START (Nat. Consortium for the Study of Terrorism and Responses to terrorism) (2016), GTD Global Terrorism Database. Codebook: Inclusion Criteria and Variables, Univ. Maryland, https:// www.start.umd.edu/gtd/downloads/Codebook.pdf.

UM S., CROMPTON J.L. (1990), “Attitude determinants in tourism destination choice”, Annals of Tourism Research, 17, 3, pp.432-448.

VANNESTE D., VANDEPOEL M. (2012), “Gender, still a power issue for use of public space by visitors and tourists? Test case Brussels", in Presentation \& abstract, International Geographical Union (IGU), Trier, pp. 22-25, August 2012.

WAHAB S. (1996), "Tourism and Terrorism: Synthesis of the Problem with Emphasis on Egypt", in PIZAM A., MANSFELD Y. (eds.), Tourism, Crime and International Security Issues, New York, John Wiley, pp. 175-186.

WILSON E., LITTLE D.E. (2008), “The Solo Female Travel Experience: Exploring the "Geography of Women's Fear"', Current Issues in Tourism, 11, 2, pp. 167-186.

WOLFF K., LARSEN S. (2014), “Can terrorism make us feel safer? Risk perceptions and worries before and after the July $22^{\text {nd }}$ attacks", Annals of Tourism Research, 44, pp. 200-209.

YECHIAM E, BARRON G. \& EREV I. (2005), “The Role of Personal Experience in Contributing to Different Patterns of Response to Rare Terrorist Attacks", Journal of Conflict Resolution, 49, 3, pp. 430-439.

\section{APPENDIXES}

Annex 1. Number of tourists in 2015 (full year)

\begin{tabular}{|c|c|c|c|c|c|c|}
\hline & \multicolumn{3}{|c|}{ Arrivals } & \multicolumn{3}{|c|}{ Overnight stays } \\
\hline & Total & Belgian & Foreign & Totaal & Belgian & Foreign \\
\hline Belgium & 15.846 .926 & 7.492 .173 & 8.354 .753 & 38.380 .415 & 19.528 .328 & 18.852 .087 \\
\hline Flemish region & 9.265 .307 & 4.911 .057 & 4.354 .250 & 24.379 .810 & 14.137 .566 & 10.242 .244 \\
\hline Walloon region & 3.227 .720 & 1.881 .517 & 1.346 .203 & 7.557 .392 & 4.157 .513 & 3.399 .879 \\
\hline Brussels Capital Region & 3.353 .899 & 699.599 & 2.654 .300 & 6.443 .213 & 1.233 .249 & 5.209 .964 \\
\hline
\end{tabular}

http://statbel.fgov.be/nl/modules/publications/statistiques/

arbeidsmarkt_levensomstandigheden/arrivees_et_nuitees_touristiques.jsp

Annex 2. Number of visitors walking through the streets of Brussels (women who think Brussels is/ is not safe; men who think Brussels is/is not safe) based on a field survey, 2011 

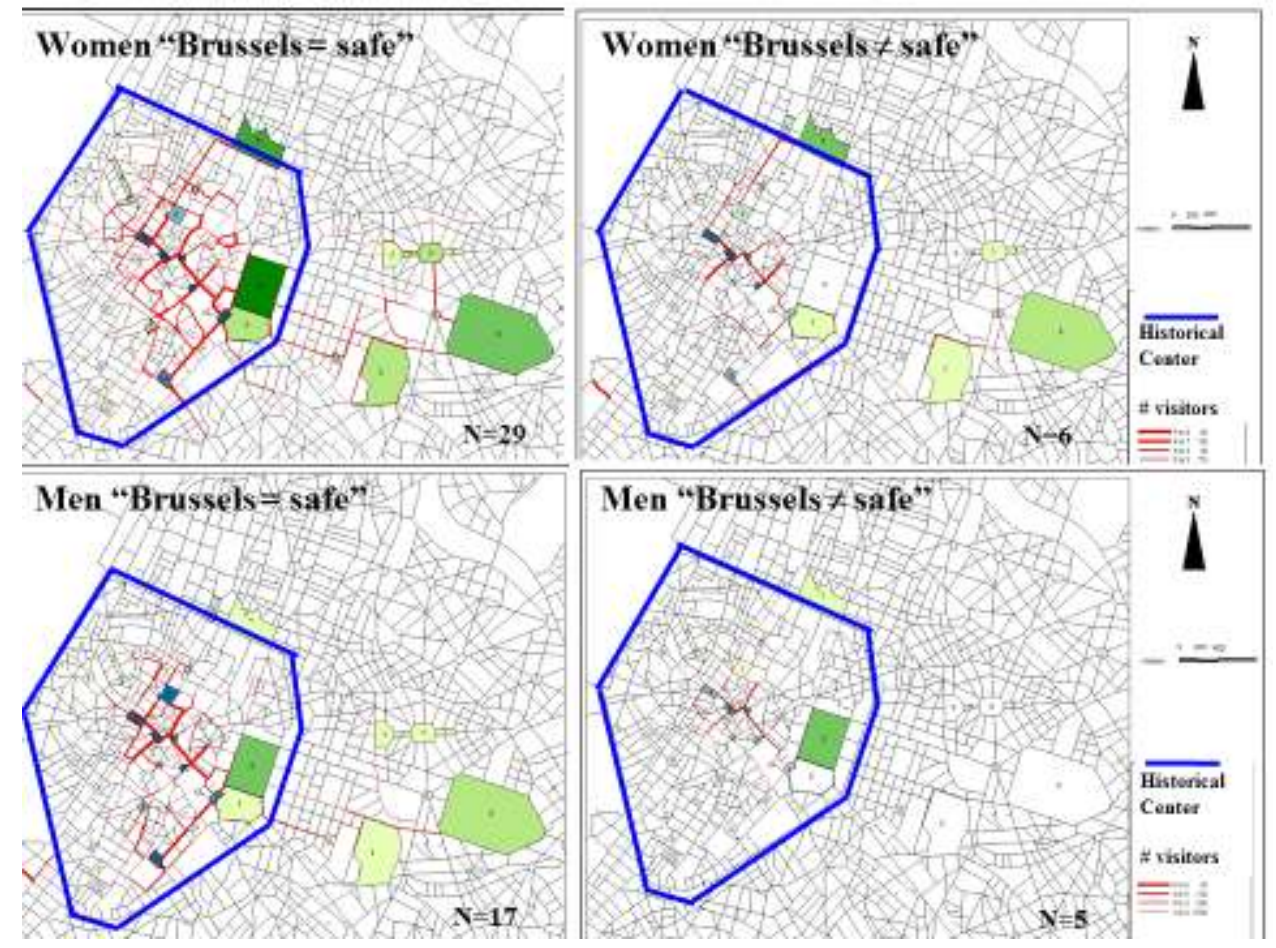

Source: Vanneste \& Vandepoel, 2012; based on a survey carried out by M. Vandepoel in 2011

\section{NOTES}

1. On March 22, 2016 two locations where attacked with explosives, Brussels Airport (at the commune of Zaventem) and Maelbeek Subway Station, located near the European District. From this incident resulted 35 casualties (including the 3 attackers) and 300 injured.

2. Population Brussels Capital Region 1/1/2016; source: Federal Public Service Economy Statistics Belgium.

3. https://www.brugge.be/bijna-8-miljoen-bezoekers-voor-brugge-in-2015.

4. https://www.start.umd.edu/gtd/downloads/Codebook.pdf (p.9).

5. Overnight stays, first 9 months: Dutch visitors: 1.958 .926 in 2015; 1.915 .715 in 2016; German visitors: 1.041 .252 in 2015, 925.847 in 2016; French visitors: 1.416 .369 in 2015, 1.206.927 in 2016; English visitors: 1.009 .011 in 2015, 821.546 in 2016.

6. http://www.toerismevlaanderen.be/sites/toerismevlaanderen.be/files/assets/ documents_KENNIS/cijfers/Voorlopige\%20cijfers/2016_Summary-9m-ENG.pdf.

http://www.toerismevlaanderen.be/sites/toerismevlaanderen.be/files/assets/ documents_KENNIS/cijfers/Voorlopige\%20cijfers/2016_Tabellen-9m.pdf.

7. Depending on the registration system of the hotel manager (based on passport or e-booking) the country of origin can be the nationality or the country of residence.

8. Figures for the entire year 2016, month by month, were not available at the moment this paper was written.

9.

http://www.hln.be/hln/nl/32616/Terreurdreiging-in-Belgie/article/ detail/2533626/2015/11/23/Lockdown-Brussel-wereldwijd-voorpaginanieuws.d.html.

10. Focusing on stays for leisure purposes in $2011,39 \%$ of the hotel reservations in the Art Cities were made in between 1 and 3 months in advance (32\% for B\&B) and 19\%, even more than 3 
months in advance ( $20 \%$ for B\&B); for Brussels, $45 \%$ of the reservations are made in between 1 and 3 months in advance and 30\%, more than 3 months in advance (Toerisme Vlaanderen en de Vlaamse Kunststeden, De recreatieve verblijfstoerist in de kunststeden (2011), table 2,50, https:// www.toerismevlaanderen.be/kunststeden\#onderzoek).

11. https://www.weforum.org/agenda/2015/11/how-do-economies-recover-after-terroristattacks/

12. http://www.hln.be/hln/nl/36484/Aanslagen-Brussel/article/detail/2751266/2016/06/19/ Opnieuw-gelach-in-de-vertrekhal-van-Brussels-Airport.dhtml, http:// www.toerismevlaanderen.be/nieuws/shareoursmile-een-campagne-voor-en-door-detoeristische-sector.

\section{ABSTRACTS}

Scientists as well as the general public remember the terrorist attacks that took place in Brussels in March 2016. This was not a stand-alone event since other places were hit previously. This changes people's perception of places - in tourism terms, destinations - and may affect tourists' behavior.

In this paper, we explore the effects on two levels. First we compare, for 2015 and 2016, the month-by-month evolution of the number of (international) arrivals, overnight stays and hotels' occupancy rates which tend to respond very quickly, affected by tourists staying away. It is much more difficult to detect changes of feelings and attitude among tourists. We explored the latter via a survey in Brussels and also in Antwerp and Bruges as a kind of benchmark.

The results represent bad and good news for the tourism industry in Brussels and Belgium and for Brussels/Belgium as a destination. The bad news is that terrorist attacks did not pass unnoticed. On the contrary, they had an effect on the visitors' behavior in terms of arrivals and overnight stays (with effects on e.g. hotel occupancy) for several months. We see that the effects are felt far beyond the place that suffered from the attack(s), particularly if this place is a brand for the region or for the country. The good news is that tourists, after ca. six months, seem to feel safe again. Therefore, our results are in line with the international literature but our attention is drawn towards the fact that some did adapt their behavior by self-moderation and by avoiding certain places from a safety perspective as well as differences among countries of origin.

Les scientifiques comme le public se rappellent les attaques terroristes de mars 2016 à Bruxelles. Ces événements ne constituaient pas un élément isolé dans la mesure où d'autres endroits furent également touchés. Cela change la perception des gens concernant certains lieux - en termes touristiques, les destinations -, ce qui peut influencer l'attitude des touristes.

Dans cette contribution, nous explorons les effets de ces attentats à deux niveaux. D'abord, pour 2015 et 2016, nous comparons l'évolution, mois par mois, du nombre d'arrivées (internationales), des nuitées et des taux d'occupation dans l'hôtellerie qui réagissent très vite à ce genre d'événements en raison du nombre de touristes qui annulent leur voyage ou décident de ne pas venir. Il est plus difficile de sonder les changements d'appréciation et de comportement parmi les touristes. C'est pourquoi nous avons exploré cet aspect au moyen d'une enquête menée à Bruxelles ainsi qu'à Anvers et Bruges, prises comme références.

Les résultats représentent à la fois de bonnes et de mauvaises nouvelles pour l'industrie du tourisme à Bruxelles et en Belgique et pour Bruxelles/Belgique en tant que destination. La 
mauvaise nouvelle, c'est que des attaques terroristes laissent des traces. Elles ont un effet sur les comportements en termes d'arrivées et de nuitées (et donc sur les taux d'occupation hôtellerie) pendant plusieurs mois. En outre, ces effets sont aussi ressentis loin de l'endroit qui a souffert de l'attaque, en particulier si cet endroit constitue une marque de la région ou du pays. La bonne nouvelle, c'est qu'au bout de six mois les touristes semblent se sentir en sécurité de nouveau. Ainsi, nos résultats sont en ligne avec la littérature internationale mais il est clair également que certains adaptent leur comportement par une auto-modération et par un réflexe d'évitement de certains endroits à cause des problèmes de sécurité, quoique différemment selon le pays d'origine.

INDEX

Keywords: tourism, terrorist attacks, Brussels, safety, quantitative effects, qualitative effects, tourist behavior

Mots-clés: tourisme, attaques terroristes, Bruxelles, sécurité, effets quantitatifs, effets qualitatifs, comportement des touristes

\section{AUTHORS}

\section{DOMINIQUE VANNESTE}

University of Leuven (KU Leuven), Faculty of Science, Division of Geography and Tourism, dominique.vanneste@kuleuven.be

\section{PETRONELA TUDORACHE}

Bucharest University of Economic Studies, Faculty of Business and Tourism, Erasmus + Intern at KU Leuven 2016, tudorachep@yahoo.com

\section{FLAVIA TEODOROIU}

Bucharest University of Economic Studies, Faculty of Business and Tourism, Erasmus + Intern at KU Leuven 2016, flavia.teodoroiu@yahoo.com

\section{THÉRÈSE STEENBERGHEN}

University of Leuven (KU Leuven), Faculty of Science, Division of Geography and Tourism, therese.steenberghen@kuleuven.be 